\title{
Leadership Strategies and Policies on Online Learning during the Covid-19 Pandemic: A Case Study
}

\section{MARZUL HIDAYAT ${ }^{1}$ AND RUDI HARTONO ${ }^{2}$}

\begin{abstract}
Educational institutions around the world have closed due to the COVID-19 pandemic endangering the academic agendas. Educational institutions have to shift to online learning platforms to keep the educational activities working. Nonetheless, the questions about the educational leadership strategies and policies of online learning are not clearly understood yet, principally for a developing country like Indonesia, where the technical constrictions like access to the Internet have become a serious issue. In this study, we focused on finding out the leadership strategies and policies of the heads of the postgraduate study programs and looking at the entire cycle in the learning process by looking at the implementation and evaluation of the goals of online learning during the pandemic. The study design was qualitative in the case study approach. Seven participants were willing to get involved in this study. The primary data sources were in-depth interviews with seven participants who are the heads and secretary of the postgraduate program at one public university in Jambi. We examined our interviews data by using within-case and cross-case displays and analyses. We categorized our analysis and discussion about our participants' perspectives and the contexts in which leadership strategies and policies of online learning they managed emerge. The analysis of our texts revealed that major issues related to the causes and covid-19: the rapid, unpredictable and 'forced' transition from face-to-face teaching to distance or online teaching, leadership strategies and policies in online learning, and evaluating teaching and learning processes: "assessing its achievements and improving upon its effectiveness." Future education research and implications are also discussed.
\end{abstract}

\section{Keywords}

Inhibiting factors, online pedagogy the rapid, unpredictable and 'forced' transition

${ }^{1}$ Assistant Professor and Faculty member, Universitas Jambi, Jambi, Indonesia; Corresponding author: mhiday2012@gmail.com

${ }^{2}$ Student of master's program in educational management, Universitas Jambi, Indonesia.

\section{Introduction}




\section{IRJE | Indonesian Research Journal in Education | |Vol. 5| No. 2| Dec |Year 2021|}

The spread of the Corona virus is not only in its country of origin, namely Wuhan China, but also spreads to all parts of the world, based on the WHO report globally on November 15, 2020 reaching 53,507,282 people who were exposed to confirmed cases of COVID-19 while the death rate reached 1,305,164 soul (WHO, 2020). The condition of the spread of the Corona virus that is getting worse has made various efforts to break the chain of transmission of Covid-19, the spread of this virus has an impact on people's lives, both economic, social and even the world of education is affected by the Corona virus. This is recognized by UNESCO that the corona virus has had an impact on the education sector, where at least 300 million students around the world would be disrupted in learning activities (Kompas, 2020). Indonesia is one of the countries affected by the spread of Covid 19. Based on data from the Task Force for Handling Covid-19 on November 15, 2020, the transmission of the corona virus reached 467,113 people (Kompas, 2020). The Indonesian government has previously taken anticipatory steps for the spread of the Corona Virus in Indonesia, especially in the field of education, namely the issuance of policies that require online learning at all levels of education. This policy is an effective step that can be taken during the pandemic, because interactions between humans do not have to meet, in today's modern times, communication can be done through print media, technology, and social media.

In preventing the spread of Covid-19, WHO has advised to stop events that can cause crowds. Therefore, face-to-face learning that gathers many students in the classroom is reviewed for its implementation. Lectures must be held with scenarios that are able to prevent physical contact between students and lecturers and students and students. According to Milman (2015), the use of digital technology can enable students and lecturers to carry out the learning process even though they are in different places. The form of lectures that can be used as a solution during the COVID-19 pandemic is online learning. According to Moore, Dickson-Deane, and Galyen (2011), online learning is learning that uses the internet network with accessibility, connectivity, flexibility, and the ability to bring up various types of learning interactions. Research conducted by Zhang et al. (2006) shows that the use of the internet and multimedia technology is able to change the way knowledge is delivered and can be an alternative to learning carried out in traditional classrooms. Online learning is learning that is able to bring together students and lecturers to carry out learning interactions with internet assistance. At the implementation level online learning requires the support of mobile devices such as smartphones or Android phones, laptops, computers, tablets, and iPhones that can be used to access information anytime and anywhere (Gikas \& Grant, 2013). The online learning policy is implemented in universities, based on the Joint Decree of the four Ministers Number 01/KB/2020 dated June 15, 2020, stating that the learning process, especially at the higher education level in the odd semester of the 2020/2021 academic year in all zones, must be held online for theoretical subjects (Directorate General of Higher Education Kemdikbud RI, 2020). Various policies issued by both the central government and from the campus make online learning need to be strengthened. Online learning has become a demand in the world of education since the last few years (He, Xu, \& Kruck, 2014). Face-to-face learning is considered closed and as a 


\section{IRJE | Indonesian Research Journal in Education |}

|Vol. 5 | No. 2|Dec|Year 2021|

traditional learning model, nowadays so that online learning facilities are needed by utilizing technology and social media (Paningrahi, Srivastava, \& Sharma, 2018).

In Indonesia, especially at the research site, online learning is a new learning model, for that it is necessary to identify the leadership strategies and policies used by the leaders of the study program heads at the at the research site in implementing online learning. It needs to be input into the education system by head of the study program to improve the institution in reaching market segments (Allen \& Seaman, 2003). The purposes of this research was to find out the leadership strategies and policies of the heads of the postgraduate study programs and to look at the entire cycle in the learning process by looking at the implementation and evaluation of the goals of online learning.

\section{Literature Review}

\section{Use of technology in distance or online teaching}

The results of the latest research on the use of technology for online and offline teaching in Indonesia in the non-Covid-19 era show that there are challenges for both prospective teacher students and lecturers in their implementation. Recent research on the use of technology in distance or online teaching in Indonesia, among others, was conducted by Mukminin, Habibi, Muhaimin, and Prasojo (2020) who examined the behavior of prospective English teachers in using the "m-learning management system" in learning activities. These students are strongly influenced by various factors including supporting conditions, self-efficacy, perceived ease of use, subjective norms, perceived usefulness, and attitudes possessed by prospective teachers. Furthermore, Mukminin, Fridiyanto, and Habibi (2020) also conducted research on the use of ICT in the classroom showing that all teachers have more knowledge about traditional, non-technology conceptions of pedagogy, and content than technological pedagogy and technological content. This shows that the ability of teachers or lecturers to use ICT in teaching is still weak.

The issue of the importance of using technology in distance or online teaching by student teacher candidates at the university level is also a study of the research of Habibi, Razak, Yusop, and Mukminin (2019) which found that quantitatively and qualitatively they had a positive attitude towards the use of ICT, but lacked effective in implementation in the online classroom. These results are supported by the results of research by Aman, Prasojo, Sofwan, Mukminin, Habibi, and Yaqin (2020) that perceived usefulness and perceived ease of use, subjective norm and attitudes of self-efficacy and supporting conditions are very influential in the successful use of technology in teaching. In terms of the challenges of using technology in online teaching, the research of Prasojo, Mukminin, Habibi, Hendra, and Iqroni (2019), Prasojo, Habibi, Yaakob, Mukminin, Haswindy, and Sofwan (2019), Prasojo, Mukminin, Habibi, Marzulina, Sirozi, and Harto (2018) found that there are barriers to ICT integration in the classroom, including teacher knowledge about ICT, funding for ICT, traditional teaching styles, professional development, and school culture. Meanwhile, research by Marzulina, Habibi, Mukminin, Desvitasari, Yaakob, and Ropawandi (2018) found that two obstacles in using technology in online teaching are lack of skills and cost of use. 


\section{IRJE | Indonesian Research Journal in Education | \\ |Vol. 5| No. 2| Dec |Year 2021|}

\section{Remote or online teaching during the covid-19 pandemic}

The term "online platform" is growing in popularity and has been used to describe various services available on the Internet, specifically in the field of education including search engines, social media (whatsapp), Zoom, google meet, Online Video Conferences, Colibri, and others during the Covid-19Pandemic. An online platform is defined as a digital service that facilitates interaction between two or more distinct but interdependent sets of users who interact through the service over the Internet. Online teaching using platforms such as Zoom, google meet, Online Video Conferences, Colibri, etc. has been widely promoted during the Covid-19 Pandemic by various countries including Indonesia. Various recent studies in the context of teacher education and distance or online teaching during the Covid-19 pandemic have been carried out with varying results. For example, research conducted by Zhang et al. (2020), Judd et al. (2020), and Huber and Helm (2020) found that the impact of COVID-19 on teaching is happening and being experienced by governments, institutions, and stakeholders in many parts of the world.

The transition from face-to-face teaching to online teaching occurred suddenly and unexpectedly and has raised several pedagogical challenges, not only in terms of teaching methods but also related to strategies and assessment tools. Carrillo and Flores (2020) who analyzed 134 previous studies suggest that in teacher education during the COVID-19 era, it is necessary to make comprehensive changes to online pedagogy that integrates technology to support the teaching and learning process. Furthermore, research by Adedoyin and Soykan (2020) shows that despite the sudden migration of the teaching process in teacher education to online platforms during this pandemic, the challenges experienced by lecturers and student teacher candidates can be well explored and turned into opportunities. According to Adedoyin and Soykan (2020), online learning will be sustainable and education will become more hybrid. Also research conducted by Kidd and Murray (2020) on the effects of Covid-19 and teacher education in the UK found that despite the relocation to the newly created online space, many of the principles and practices of 'intentionalities' have remained unchanged in teacher education.

\section{Leadership strategies and policies in online learning}

In an educational institution, especially higher education levels, the head of the study program has an important role in a policy during the strategic learning processes. The head of the study program is the leader in the study program as the key to the implementation and development of the study program. The head of the study program is responsible for improving and sustaining the student learning process and matters related to the study program. To achieve success in implementing learning during the pandemic, especially after the online learning process has been determined, the head of the study program must have strategic leadership. Research conducted by Alotebi, Alharbi, and Masmali (2018) also suggests that leadership in a virtual or online environment refers to leaders being able to influence the behavior of others through online learning media, where the findings of this study state that 


\section{IRJE | Indonesian Research Journal in Education | |Vol. 5| No. 2| Dec|Year 2021|}

transformational leadership strategies are better used in learning online rather than transactional leadership strategies because transformational leadership strategies improve performance, leadership satisfaction, and group cohesiveness. Northouse (2018) state that the leadership strategy is divided into two, namely the first is the transformational leadership strategy and the transactional strategy. Transformational leadership is part of a new leadership paradigm that emphasizes charismatic and effective components in leadership, an approach that changes and transforms individuals, which focuses on the intrinsic motivation of its members. While transactional leadership is transactional leadership which refers to the exchange of relationships between leaders and members, this leadership model does not want change in an organization.

\section{Methodology}

\section{Research design, site, and participants}

This research used a qualitative method with a case study approach. According to Marshall and Rossman (1999), qualitative research has the aim of multiplying, explaining and describing the phenomenon of interest to explore, explain, or describe the phenomenon of interest. Meanwhile, according to Merriam (1998), qualitative research methods are methods that prioritize process, meaning, and understanding because the product of qualitative research is "richly description" and case studies are one type of qualitative research (Creswell, 1998). The selection of the case study approach is also in accordance with what Merriam (1998) said that a case can be a person, a program or an institution. In this research, the "case" is the leadership strategies and policies in the implementation of online learning during the Covid-19 Pandemic. The location of this research was carried out in several postgraduate study programs in a state university. This study was conducted from January to May 2021. The selection of research locations also paid attention to access to obtain research data. Access is very important in qualitative research because it would affect how data would be obtained and who would provide data. To gain access to the research site, researchers used various networks and relationships that had been established.

In the process of determining the informants, the researchers had people who understood the problems being studied, namely by using purposive sampling with a naturalistic orientation. The sample in this study was used to explore information of processes or activities or actions of several people who act as heads of the study program in order to obtain in-depth information about leadership strategies in the implementation of online learning during the covid-19 pandemic period. The participants in this study were 7 people consisting of the 6 Heads of the Study Programs and one secretary of the study program with a doctoral education level of all participants. The ages of participants were between 46 years and 62 years old.

\section{Data collection and analysis}




\section{IRJE | Indonesian Research Journal in Education | |Vol. 5 | No. 2| Dec |Year 2021|}

Interview is the data collection method which is most often used by researchers when researching something that has happened in the past because it will not happen again, this is in accordance with what Merriam (1998) stated that interviewing was a preferred data collection method when researchers want to examine past events, which are not possible to happen again. In this research, interviews were carried out with an interview protocol. The type of interview that was carried out in the data collection process was a semi-structured interview focusing on leadership strategies and policies in online learning during the COVID-19 pandemic. Research participants were interviewed about leadership strategies and policies regarding online learning during the COVID-19 period in relation to planning, organization, coordination, and control. Each participant's interview lasted from thirty minutes and one hour. All 7 participants were asked to discuss their experiences about their leadership strategies and policies regarding online learning during the COVID-19 period. We developed the interview questions based on the previous research and the authors digitally recorded each participant's accounts and responses via a digital voice recorder.

In terms of the qualitative data analysis, Miles and Huberman (1994) wrote, "Qualitative data ...are a source of well-grounded, rich descriptions and explanations of processes in identifiable local contexts...” (p.1). Moreover, Marshall and Rossman (1999) claimed that qualitative data analysis was "a messy, ambiguous, time-consuming, creative, and fascinating process" (p. 150) while "Undoubtedly, no consensus exists for the analysis of the forms of qualitative data" (Creswell, 1997, p.140). For analyzing the interview data in our study, once the audiotaped interviews were transcribed, they were reviewed line-by-line so as to discover consistencies, patterns, and emerging topics. Additionally, the transcriptions were reread with the temporary lists of codes that had been created. The temporary lists of codes were employed as a guide to develop inductive codes and themes. Moreover, we used within-case and cross-case displays (Miles \& Huberman, 1994) to distribute interviews data in an attempt to record every significant account related to the focus of the study among the cases (participants) that was finally used to make final themes.

\section{Trustworthiness}

To establish the trustworthiness of data, interpretations, and conclusions, we shared our findings with the respondents to have their feedback. Lincoln and Guba (1985) state that this is "the most critical technique for establishing credibility" (p.314) of the data or findings. We also provided rich and thick descriptions (Merriam, 1998) and narratives of participants' leadership strategies and policies regarding online learning during the COVID-19 period by including verbatim examples from the transcribed interviews data. To protect the rights of human participants, we also masked the names of people, places, and the research site through the use of pseudonyms for the participants, places, and research site while participation in this study was voluntary.

\section{Findings}

In order to find out the causes of the online learning, the implementation of the leadership strategies in the implementation of online learning, and the supporting factors and 


\section{IRJE | Indonesian Research Journal in Education | \\ |Vol. 5| No. 2|Dec|Year 2021|}

inhibiting factors in the application of online learning at the postgraduate study programs, we asked our participants to describe and discuss their experiences, feelings, and thoughts on leadership strategies and policies on online learning during the Covid-19 pandemic. In the following, we present the major issues related to leadership strategies and policies on online learning during the Covid-19 pandemic.

\section{The causes and Covid-19: The rapid, unpredictable and 'forced' transition from face-to-face teaching to distance or online teaching}

The online learning did not just happen at the research site, but it was caused by the COVID-19. To anticipate the worse impacts on education, the Indonesian government was forced to produce regulations requiring all campuses to apply online learning due to the rapid, unpredictable and 'forced' changes in the pandemic era. Our participants reported that they were forced to use online learning due to the unpredictable situations on their campus and students and lecturers were worried about their health and safety. For example,

"In Indonesia, the Covid-19 pandemic has led to the closure of campuses and universities. Due to the closure of campuses and universities, it has affected the educational process, including the education process in the program that I lead. Study programs, lecturers and students must quickly adapt to distance or online teaching. The need to create a good learning atmosphere for doctoral students is needed to make decisions, choices, and adaptations in order to meet not only their own expectations but also the requirements of doctoral candidates that must be facilitated by the study program.” [Participant 1]

Participants generally reported that they had a variety of students from different places that had to be facilitated by the program. If online learning was not used by the program, students and lecturers were worried about their safety. In the words of one of the participants,

"The reason for the implementation of online learning is, of course, because of the current pandemic, because students who are studying on this post-graduate campus are not only from one area but also from outside the region.” [Participant 3]

Participants also indicated that they had to follow the government regulations for implementing online learning in order to stop the spread of the pandemic.

"The online learning is carried out in Indonesia is none other than the current Covid-19 condition, making us switch lectures from face to face to online one." [Participant 5]

The transcripts of the interviews demonstrated that our participants obeyed the government regulations to implement the online learning whether they were ready or not. They felt that 


\section{IRJE | Indonesian Research Journal in Education |}

|Vol. 5 | No. 2|Dec|Year 2021|

they had to do it in order to keep everybody healthy while educational processes were still running well.

\section{Leadership strategies and policies in online learning}

The online learning that takes place due to the covid-19 pandemic makes a leader must be able to overcome changes that occur for the smooth implementation of online learning. A leader's strategy in dealing with changes needs to be done so that lectures can take place. Our participants generally indicated that they had several strategies dealing with the online learning due to the rapid, unpredictable and 'forced' changes in the pandemic era among other things: changing the learning system, creating whatshapp groups, providing teaching and learning media, and managing inhibiting factors for online learning at the postgraduate study programs

\section{Changing the learning system: From designing, determining, compiling, to implementing learning}

All of the interviewees reported that the first strategy was to make changes to the learning system, particularly schedules. Our participants reported that they had to change the schedules due to the situation of the pandemic. For them, it was not easy to do it because teaching totally online was not easy for some professors who were not familiar with technology such as zoom or Google meet while there was no specific training to anticipate such changes. For example, one of our participants reported,

"The rapid, unexpected, and 'forced' transition from face-to-face teaching to distance or online teaching due to the Covid-19 pandemic has given rise to a number of complex challenges and obstacles so that the program requires various strategies to achieve the goals the program. First, all teaching and learning processes starting from designing, determining, compiling, and implementing learning during the pandemic are carried out online, namely through Google meet or zoom. All lecturers and students inevitably have to study online. All study materials, coursework, and assessments of the teaching and learning process are carried out online and paperless." [Participant 1]

Here, it can be revealed that our participants had to prepare and involve all stakeholders to do online learning starting from designing, determining, compiling, to implementing learning which was not easy for them because it was done in a rapid and forced transition. For our participants, preparing teaching and learning including materials, coursework, and assessments was very challenging during the pandemic. Our participants had to ensure that designing, determining, compiling, and implementing learning were fully carried out by all professors. However, changing the learning system was the only way for them to have otherwise teaching and learning processes would not happen during the pandemic. 


\section{IRJE | Indonesian Research Journal in Education |}

|Vol. 5 | No. 2|Dec|Year 2021|

Additionally, our participants reported that this change was experienced by education section around the world.

\section{Creating whatshapp groups: Designing academic dialogs among students, lecturers, and administrators}

Another interesting strategy that our participants generally designed was making whatshapp groups for their student, lecturers, and administrators, and heads of the program. These kinds of strategies helped participants and their students and lecturers keep everything updated related to teaching and learning processes.

"Students are included in a WA group so that all information for the online learning processes can be received by students directly. In the WA group, active students and alumni are joined so that they can provide input to each other if there are difficulties in the online learning process." [Participant 7]

“......lecturers and students are included in the Wa group.” [Participant 4]

"Office needs, student study programs do not need to be face-to-face for correspondence purposes, we can use WhatsApp or now there is PLO, then information on academic issues is conveyed through the WhatsApp group." [Participant 1]

The whatshapp groups were used by our participants to cut the problems that would emerge before, while, and after the teaching and learning processes. Our participants as the leaders of the programs felt that the groups were enough effective to help not only the students, but also

the lecturers. Additionally, according to our participants, there had been a lot of academic dialogs among students, lecturers, and administrators with the groups.

\section{Providing teaching and learning media: "Teaching and learning processes must go on during the pandemic"}

A leader must have a strategy in carrying out the implementation of online learning, the strategy used determines the success of the online learning. One of the learning leadership strategies that our participants had was to provide learning media for students and lecturers. Learning media is used as a means of supporting the learning process for learning objectives can be achieved. Teaching Learning media were important for lecturers in conveying teaching materials to students to be more effective and efficient during the pandemic.

"The strategy I use in implementing online learning is to provide learning media such as zoom, which is important during the pandemic." [Participant 3]

"The strategy I take is that I use several platforms, existing platforms such as zoom, Google classroom, but at the university level, Google classroom is not used, most of 


\section{IRJE | Indonesian Research Journal in Education | |Vol. 5| No. 2|Dec|Year 2021|}

them use zoom which is indeed provided, some study programs provide zoom, some are done independently by the students themselves." [Participant 4]

"The strategy in implementing online learning is currently first the learning process carried out online is provided with media such as zoom, google meet or whatsapp group." [Participant 5]

"The strategy used by the head of the study program in implementing online learning during the current pandemic, firstly provides learning media, where currently the media that is often used is zoom, our own study program uses a paid zoom so that it is not interrupted when learning takes place because it is disconnected....."

Participant 6]

By providing teaching and learning media, our participants expected that the media can be used to maintain active learning teaching and student projects as media could provide a useful platform for teaching during the pandemic such as cases, cooperative learning, problem solving, and interactive lecture demonstrations. Our participants had worked hard to anticipate what would hurdle their students' learning.

\section{Managing inhibiting factors for online learning at the postgraduate study programs}

Our participants commented that they had to manage the barriers of online learning. They felt that the online learning might create a sense of isolation as every student learns in his or her own way. Also, online learning needs students' self-discipline otherwise, it would not happen. Our participants also commented that additional training for lecturers is required to anticipate technical issues.

"We have to take care everything during the online learning. Lecturers and students have to be reminded that they classes in specific time. The online learning produces many problems such as students' isolation, lecturers' lack of technology." [Participant 4]

"You know, it is not easy to manage lecturers and students during the online learning, some lecturers are able to use online learning, and some are not. It happens to students as well." [Participant 2]

Additionally, our participants commented that they had to manage such as cost and access to the Internet, administrative issues, social interactions, academic skills, learner motivation, time and technical problems.

"Several inhibiting factors in online learning include (1) difficulties or obstacles related to online learning infrastructure such as poor and less modern connections or sophisticated mobile phones or laptops, (2) many senior lecturers who are less familiar with online learning, (3) limited online learning resources in Indonesian, (4) there are still many lecturers who have difficulty adapting curriculum content to 


\section{IRJE | Indonesian Research Journal in Education |}

|Vol. 5 | No. 2|Dec|Year 2021|

online learning, (5) seriousness of student involvement in online learning is still questionable, (6) the final assessment process is still not uniform among lecturers." [Participant 1]

However, although all participants were challenged by inhibiting factors in online learning, none of them complained about the teaching and learning processes in their study programs. Instead, they were able to manage the inhibiting issues and tried to find the ways out.

\section{Evaluating teaching and learning processes: "Assessing its achievements and improving upon its effectiveness"}

Our participants expressed that they evaluated the teaching and learning processes. The purposes of the evaluation are to look at objectives, learning experiences, learner assessment, and the relationship among the three. They commented that evaluation was important to look at the effectiveness of teaching, teaching strategies, methods, and techniques during the pandemic. It provided them with feedback for improving their services for lecturers and students as they did not know when the pandemic would end. Evaluation of teaching and learning processes during the pandemic involved gathering evidence from students and lecturers for improving the effectiveness of the teaching-learning process.

"Evaluations are carried out at the end of online learning through website, email, or there are also through interviews. We asked students and lecturers. We evaluate the processes to asses our achievement and improve the effectiveness." [Participant 3]

"For the evaluation of online learning, it is again submitted to the lecturer in question.” We ask about students' achievement and the effectiveness.”[Participant 7]

Our participants did the evaluation to help to assess the achievement and to improve upon its effectiveness. For our participants, the improvement related to courses/curricula, texts, and teaching materials is important to do during the pandemic.

"Evaluation plays an important role in the teaching-learning processes during the pandemic. It helps us, lecturers, and students to improve teaching and learning and the most important thing is that it is an unceasing process and a periodic exercise." [Participant 4]

For our participants, during the pandemic how much every student has succeeded in his/her goals can only be concluded through an evaluation as there is a close association between evaluation and learning goals.

\section{Discussion}




\section{IRJE | Indonesian Research Journal in Education | |Vol. 5| No. 2| Dec |Year 2021|}

The Covid-19 pandemic has not ended at national borders. It has influenced people irrespective of their nationality and level of education. For education, leaders should find out the ways out for keeping students have a quality education. The purposes of this research was to find out the leadership strategies and policies of the heads of the postgraduate study programs and to look at the entire cycle in the learning process by looking at the implementation and evaluation of the goals of online learning. Our findings indicated that participants in this study were challenged by the rapid, unpredictable and 'forced' transition from face-to-face teaching to distance or online teaching. However, our participants managed to anticipate the sources of the problems in online teaching and learning by changing the learning system, creating whatshapp groups, providing teaching and learning media, and managing inhibiting factors for online learning at the postgraduate study programs.

One of the interesting findings in our study was that our participants changed the learning system from face to face to "total online learning" which resulted in many emerging issues such as the unfamiliarity of lecturers with using platforms (e.g., zoom, Google meet). In the words of Carrillo and Flores (2020), Adedoyin and Soykan (2020), Mahdy (2020), Almendingen, Morseth, Gjølstad, Brevik, and Tørris (2021), there is the need for a comprehensive assessment of the online education that mixes technology to support teaching and learning during the pandemic.

Our findings also indicated that participants managed inhibiting factors for online learning such as cost and access to the Internet, administrative issues, social interactions, academic skills, learner motivation, time and technical problems. Our findings are in line with what Zalat, Hamed, and Bolbol (2021) found in their study that the highest obstacles to online learning were insufficient/ unstable internet connectivity, inadequate computer labs, lack of computers/ laptops, and technical problems. Additionally, Engzell, Frey, and Verhagen (2021) found that students made little or no progress while learning from home, suggesting that online learning during the pandemic has influenced students' achievement, particularly in countries with weaker infrastructure. Our findings also suggested that as our participants started understanding the situations and conditions of teaching and learning processes during the pandemic, the barriers did not hinder them from continuing the learning processes.

The findings of our study shed light on our understanding of the leadership strategies and policies of the heads of the postgraduate study programs in dealing teaching and learning processes during the pandemic. Our findings are important to give clear information that although the pandemic has affected education harmfully, with classes and assessments being delayed or changed into the online ones due to the lockdown, our participants with their leadership strategies and policies had managed to keep teaching and learning processes happening during the pandemic. Northouse (2018) state that strong leadership strategies are important during the crises time to lead the organization to reach the common goals. Our findings also indicated that participants in this study even evaluated the processes in order to prepare what would happen in the future as the COVID-19 pandemic still jeopardizes the academic calendars. 


\section{IRJE | Indonesian Research Journal in Education | |Vol. 5| No. 2|Dec|Year 2021|}

Implications for education policies and programs can be drawn from the findings of our study. For example, as the end of the pandemic is not certain yet, the government and policy makers should anticipate the new and future challenges for online learning. For example, the connectivity and internet should become a priority for the government to deal with as for remote areas; students still struggle to have the connectivity and internet. Also, the sense of isolations for students has become a new issue in education during the pandemic, central and local governments should work to get with local universities to provide students with programs that can reduce their isolated feelings such as online working groups or visiting students in remote areas who cannot go anywhere. The isolated students will not always turn to their lecturers and most likely will wait for lecturers to initiate communication.

Our findings should be reflected in the sight of some restrictions. First of all, our participants may not be representative of all heads of postgraduate programs in Indonesia. There may be dissimilarities between the experiences faced by all heads of postgraduate programs in different programs and institutions during the pandemic. Generalizability of our findings to other heads of postgraduate programs is warned. Future studies may take account of a larger sample of heads of postgraduate programs from different universities in Indonesia, which may provide diverse perspectives. Secondly, this study was limited to 7 heads of postgraduate programs at one public university in Jambi, lecturers and students were excluded from this study, so in future research could investigate them. Also, other researchers may replicate and extend our study to heads of undergraduate programs.

\section{Conclusion}

Using a qualitative case study, this study adds to the body of knowledge on the educational leadership strategies and policies of the heads of the postgraduate study programs and looking at the entire cycle in the learning process by looking at the implementation and educational evaluation of the goals of online learning during the pandemic, including to the causes and covid-19: the rapid, unpredictable and 'forced' transition from face-to-face teaching to distance or online teaching, leadership strategies and policies in online learning, and evaluating teaching and learning processes: "assessing its achievements and improving upon its effectiveness." Findings offer insights into what 7 heads of postgraduate programs at one public university in Jambi experienced during the pandemic online learning. Although findings indicated that participants were challenged by various inhibiting barriers such as cost and access to the Internet, administrative issues, social interactions, academic skills, learner motivation, time and technical problems for online learning, participants in this study managed to deal with the barriers as education all over the world faced the same issues, particularly in developing countries.

\section{Disclosure Statement}

No potential conflict of interest was reported by the authors.

\section{Acknowledgments}




\section{IRJE | Indonesian Research Journal in Education | \\ |Vol. 5| No. 2| Dec |Year 2021|}

We would like to thanks all participants of this study for their willingness to freely share their precious experiences and insights with us.

\section{References}

Adedoyin, O. B., \& Soykan, E. (2020). Covid-19 pandemic and online learning: the challenges and opportunities. Interactive Learning Environments,1-13.

Allen, I. E., \& Seaman. J. (2003). Seizing the opportunity: The quality and extent of online education in the United States, 2002 and 2003. Wellesley, MA: Sloan Consortium.

Almendingen, K., Morseth, M.S., Gjølstad, E., Brevik, A., \& Tørris, C. (2021). Student's experiences with online teaching following COVID-19 lockdown: A mixed methods explorative study. PLOS ONE 16(8), e0250378.

Alotebi, H., Alharbi, O., \& Masmali, A. (2018). Effective Leadership in Virtual Learning Environments. International Journal of Information and Education Technology, 8(2), 156-160.

Aman, Prasojo, D. L., Sofwan, M., Mukminin, A., Habibi, A., \& Yaqin, L. N. (2020). Factors Affecting Indonesian Pre-Service Teachers' Use of m-LMS: A Mix Method Study. International Journal of Interactive Mobile Technologies (iJIM), 14(6), 137-147.

Carrillo, C. \& Flores, M. A. (2020). COVID-19 and teacher education: A literature review of online teaching and learning practices. European Journal of Teacher Education, 43(4), 466-487.

Creswell, J. W. (1998). Qualitative inquiry and research design: Choosing among five traditions. Thousand Oaks, CA: Sage Publications, Inc.

Direktorat Jenderal Pendidikan Tinggi Kemdikbud RI. (2020). Buku panduan penyelenggaraan pembelajaran semester gasal 2020/2021 di Perguruan Tinggi. Jakarta: Direktorat Jenderal Pendidikan Tinggi Kemdikbud.

Engzell, P., Arun Frey, A., \& Mark D. Verhagen, M. D. (2021).Learning loss due to school closures during the COVID-19 pandemic. PNAS 2021, 118(17), 1-7.

Gikas, J., \& Michael M. Grant, M. M. (2013). Mobile computing devices in higher education: Student perspectives on learning with cellphones, smartphones \& social media. Internet and Higher Education, 19, 18-26.

Habibi, A., Razak, R. A., Yusop, F. D., \& Mukminin, A. (2019). Preparing future EFL teachers for effective technology integration: What do teacher educators say? Asian EFL Journal, 21(2), 9-30.

He, W., Xu, G., \& Kruck, S. (2014). Online IS Education for the 21st Century. Journal of Information Systems Education, 25(2), 101-105.

Huber, S. G., \& C. Helm. (2020). COVID-19 and Schooling: Evaluation, assessment and accountability in times of crises-reacting quickly to explore key issues for policy, practice and research with the school barometer. Educational Assessment, Evaluation and Accountability, 32, 237-270. 


\section{IRJE | Indonesian Research Journal in Education | |Vol. 5| No. 2|Dec|Year 2021|}

Judd, J., B. A. Rember, T. Pellegrini, B. Ludlow, \& J. Meisner (2020). "This is Not Teaching": The Effects of COVID-19 on Teachers. https://www.socialpublishersfoundation.org/ knowledge_base/this-is-not-teaching-the-effects-of-covid-19-on-teachers/

Kidd, W., \& Murray, J. (2020). The Covid-19 pandemic and its effects on teacher education in England: how teacher educators moved practicum learning online. European Journal of Teacher Education, 43(4), 542-558

Kompas. (2020). Updating Indonesian Covid-19. Retrieved on March 2020 from https://nasional.kompas.com/read/2020

Lincoln, Y. S., \& Guba, G.B. (1985). Naturalistic inquiry. Newbury Park, CA: Sage Publications.

Mahdy, M.A.A. (2020). The Impact of covid-19 pandemic on the academicperformance of veterinary medicalstudents. Front. Vet. Sci., 7, 594261.

Marshall, C., \& Rossman, G. B. (1999). Designing qualitative research (3rd ed.). Thousand Oaks, CA: Sage.

Marzulina, L., Habibi, A., Mukminin, A., Desvitasari, D., Yaakob, M. F. M., \& Ropawandi, D. (2018). The integration of social networking services in higher education: Benefits and barriers in teaching english. International Journal of Virtual and Personal Learning Environments, 8(2), 46-62. doi:10.4018/IJVPLE.2018070104

Merriam, S. B. (1998). Qualitative research and case study applications in education. San Francisco, CA: Jossey-Bass.

Miles, M.B., \& Huberman, A.M. (1994). Qualitative data Analysis: An expanded sourcebook. San Francisco, CA: Sage Publications, Inc.

Moore, J. L., Dickson-Deane, C., \& Galyen, K. (2011). E-learning, online learning, and distance learning environments: Are they the same? The Internet and Higher Education, 14(2), 129-135.

Mukminin, A.; Habibi, A.; Muhaimin; Prasojo, L. D. (2020). Exploring the drivers predicting behavioral intention to use m-learning management system: Partial Least Square Structural Equation Model. IEEE Access, 10.1109/ACCESS.2020.3028474

Mukminin, A., Fridiyanto, \& Habibi, A. (2020). Technology in the classroom: efl teachers'technological pedagogical and content knowledge. Informatologia, 53(1-2), 24-36.

Northouse, P. G. (2018). Leadership: Theory and practice. Sage publications.

Panigrahi, R., Srivastava, P. R., \& Sharma, D. (2018). Online learning: Adoption, continuance, and learning outcome-A review of literature. International Journal of Information Management, 43, 1-14.

Prasojo, L. D., Mukminin, A., Habibi, A., Hendra, R., \& Iqroni, D. (2019). Building quality education through integrating ICT in schools: Teachers' attitudes, perception, and barriers. Quality - Access to Success, 20(172), 45-50.

Prasojo, L. D., Habibi, A., Yaakob, M. F. M., Mukminin, A., Haswindy, S., \& Sofwan, M. (2019). An explanatory sequential study on indonesian principals' perceptions on ICT integration barriers. Electronic Journal of e-Learning, 17(1), 1-10. 


\section{IRJE | Indonesian Research Journal in Education | \\ |Vol. 5| No. 2|Dec|Year 2021|}

Prasojo, L. D., Mukminin, A., Habibi, A., Marzulina, L., Sirozi, M., \& Harto, K. (2018). Learning to teach in a digital age: ICT integration and EFL student teachers' teaching practices. Teaching English with Technology, 18(3), 18-32.

WHO. (2020). Indonesia situation. Jakarta: WHO.

Zalat, M.M., Hamed, M.S.,\& Bolbol, S.A. (2021). The experiences, challenges, and acceptance of e-learning as a tool for teaching during the COVID-19 pandemic among university medical staff. PLoS ONE, 16(3), e0248758.

Zhang, D., Zhou, L., BrIggs, R., \& Nunamaker, J. (2006). Instructional video in e-learning: Assessing the impact of interactive video on learning effectiveness. Information \& Management,43(1), 15-27.

Zhang, W., Y. Wang, L. Yang, and C. H. Wang. (2020). Suspending classes without stopping learning: China's education emergency management policy in the covid-10 outbreak." Journal of Risk and Financial Management, 13 (58), 1-6.

\section{Biographical Notes}

MARZUL HIDAYAT is an Assistant Professor at Faculty of Teacher Training and Education, Universitas Jambi, Jambi, Indonesia. He obtained his doctoral degree in the Department of Educational Leadership and Policy Studies, Florida State University, the USA with a specialization on Sociocultural and International Educational Development Studies. Email: mhiday2012@gmail.com

RUDI HARTONO is a student of master's program in educational management, Universitas Jambi, Indonesia. 